EWA BIEŃKOWSKA

\title{
PROJEKT KONWENCJI NARODÓW ZJEDNOCZONYCH O SPRAWIEDLIWOŚCI ORAZ WSPARCIU DLA OFIAR PRZESTĘPSTW I NADUŻYĆ WŁADZY
}

\section{WPROWADZENIE}

Do dnia dzisiejszego najważniejszym i jedynym dokumentem o wymiarze światowym statuującym podstawowe prawa ofiar jest - przyjęta przez Zgromadzenie Ogólne Narodów Zjednoczonych w dniu 29 listopada 1985 r. - Deklaracja o podstawowych zasadach sprawiedliwości dla ofiar przestępstw i nadużyć władzy ${ }^{1}$, zwana Wielką Kartą lub Konstytucją Praw Ofiar. Od kilku lat na forum ONZ prowadzone są prace mające na celu dalsze wzmocnienie pozycji ofiar. Warto zapoznać się $z$ ich dotychczasowymi efektami, ponieważ standardy tej organizacji nie tylko stanowią kwintesencję dorobku w danej dziedzinie wszystkich jej państw członkowskich, ale oddziałują także na - poświęcone analogicznym kwestiom - regulacje o charakterze regionalnym, a w tym - europejskie. Ma to szczególne znaczenie dla państw unijnych ze względu na wiążące je prawo wtórne Unii Europejskiej, na co Komisja Europejska, wspominając również o projekcie przedmiotowej Konwencji, zwraca uwagę we wskazaniach dotyczących implementacji do wewnętrznych systemów prawnych państw unijnych postanowień dyrektywy Parlamentu

1 Resolution 34/40, Annex: Declaration of Basic Principles on Justice for Victims of Crime and Abuse of Power (tekst polski m. in. w: E. BieńkowsKa, L. MAzowieckA, Ofiara przestępstwa $w$ dokumentach międzynarodowych, Warszawa 2009, s. 71-77). 
Europejskiego i Rady 2012/29/UE z dnia 25 października 2012 r. ustanawiającej normy minimalne w zakresie praw, wsparcia i ochrony ofiar przestępstw oraz zastępującej decyzję ramową Rady 2001/220/WSiSW². Warto też dodać, że do projektu Konwencji - jako przykładu dobrej regulacji w odniesieniu do ochrony prywatności ofiar - odwołuje się Europejski Inspektor Ochrony Danych w Opinii w sprawie pakietu legislacyjnego dotyczącego praw ofiar przestępstw, w tym wniosku dotyczącego dyrektywy ustanawiającej normy minimalne w zakresie praw, wsparcia i ochrony ofiar przestępstw oraz wniosku dotyczącego rozporządzenia w sprawie wzajemnego uznawania środków ochrony w sprawach cywilnych z dnia 17 października 2011 r. $^{3}$

Przypomnijmy, że powołane do życia w 1979 r. na III. Międzynarodowym Sympozjum Wiktymologii (Münster, RFN) World Society of Victimology (WSV) jest od chwili swojego powstania głównym inicjatorem przedsięwzięć o charakterze ogólnoświatowym, których celem jest przyznanie ofiarom przestępstw właściwej pozycji i praw podmiotowych. Było ono też pomysłodawcą oraz twórcą projektu Deklaracji o podstawowych zasadach sprawiedliwości. Przed Deklaracją postawiono zadanie w postaci upowszechnienia oraz rozwinięcia praktyk traktowania ofiar już stosowanych w niektórych państwach w chwili jej przyjmowania $^{4}$, a okazała się ona instrumentem bardzo skutecznym, który doprowadził do znacznego przemodelowania sposobu postrzegania i odnoszenia się do ofiar, w tym także do ofiar najpoważniejszych

2 Por. DG Justice Guidance Document related to the transposition and implementation of Directive of the European Parliament and the Council 2012/29/EU of 25 October 2012 establishing minimum standards on the rights, support and protection of victims of crime, and replacing Council Framework Decision 2001/220/JHA, European Commission, DG Justice, 19 December 2013, s. 1-2,http://ec.europa.eu/justice/criminal/ files/victims/guidance_victims_rights_dirctive.en (w 2014 r. ma miejsce przenoszenie dokumentów w inne miejsca, jeżeli więc podana strona nie działa, należy wejść na stronę główną EUR-Lex i wpisać paramentry dokumentu).

3 Dz.Urz.UE L 35 z 9.2.2012, s. 10.

4 Bliżej E. BıEŃKowsKa, Deklaracja ONZ o podstawowych zasadach sprawiedliwości dla ofiar przestępstw i nadużyć władzy, «PiP» 42.6/1987, s. 88 i n.; EADEM, Wiktymologia. Koncepcje, kierunki badań, perspektywy, Ossolineum 1992, s. 65 i n. 
pogwałceń fundamentalnych praw człowieka i międzynarodowego prawa humanitarnego ${ }^{5}$.

Choć od początku uważano, że konieczne jest opracowanie aktu wyższej rangi, a mianowicie konwencji ${ }^{6}$, dopiero upływ czasu sprawił, że uznano tę kwestię za bardzo aktualną. Z inicjatywą taką wystąpiło WSV, które w międzyczasie uzyskało status konsultanta przy Radzie Społeczno-Gospodarczej ONZ, co bez wątpienia zwiększyło jego wpływy. Bezpośrednim bodźcem do podjęcia takiej decyzji stało się uwzględnienie w Deklaracji z Bangkoku, która została przyjęta przez XI. Kongres Narodów Zjednoczonych (Bangkok, Tajlandia, 18-25 kwietnia 2005 r.), kwestii uznania znaczenia kierowania szczególnej uwagi na potrzebę ochrony świadków i ofiar przestępstw oraz terroryzmu, jak też zobowiązania do wzmocnienia, gdzie jest to niezbędne, prawnych i finansowych ram udzielania wsparcia takim ofiarom (pkt 17) ${ }^{7}$. Idea konwencji była następnie promowana wśród uczestników kolejnego, XII. Kongresu Narodów Zjednoczonych (Salvador, Brazylia, 12-29 kwietnia 2010 r.), wśród których rozpowszechniono rekomendację WSV przyjętą z okazji 25. rocznicy uchwalenia Deklaracji o podstawowych zasadach sprawiedliwości, a nawołującą do wzmożenia działań na rzecz jej dalszego wdrażania i wskazującą jednocześnie na celowość przyjęcia konwencji ${ }^{8}$.

Pierwszy projekt Konwencji Narodów Zjednoczonych o sprawiedliwości oraz wsparciu dla ofiar przestępstw i nadużyć władzy powstał

$5 \quad$ Szerzej E. BieńкоwsкA, Standardy ochrony praw pokrzywdzonego w świetle dokumentów europejskich i ustaw zasadniczych, [w:] System prawa karnego procesowego, VI: Strony i inni uczestnicy postępowania karnego, pod red. C. Kuleszy, Warszawa (w druku).

6 Por. E. Bieńkowska, Wiktymologia. Koncepcje..., s. 75.

7 Bangkok Declaration Synergies and Responses in Crime Prevention and Criminal Justice, http://www.unocd.org/pdf/crime/congress/11/Bangkok Declaration.pdf

8 Recommendation to Acknowledge 25thAnniversary of the UN Declaration on Basic Principles of Justice for Victims of Crime and Abuse of Power and Establish an Expert Group to Report to the UN Commission of Crime Prevention and Criminal Justice in 2011, http://12thcrimecongress.wordpress.com. text-of-the-recommendation-by-the-world-society-of-victimology 
w 2006 r. ${ }^{9}$ Dostępny obecnie tekst projektu jest datowany na 8 lutego $2010 \mathrm{r}^{10}{ }^{10}$ to on jest przedmiotem dalszych rozważań.

W Preambule projektu odnotowano najważniejsze przedsięwzięcia będące następstwem implementacji Deklaracji o podstawowych zasadach sprawiedliwości i wskazano, że przyjęcie Konwencji ma służyć dalszemu wzmocnieniu ochrony interesów ofiar. Jest to - jak podkreślono - niezbędne, ponieważ miliony ludzi na całym świecie, a wśród nich wiele kobiet i dzieci, doznaje dotkliwych krzywd w wyniku przestępstw, nadużyć władzy i terroryzmu, zaś ich prawa cały czas nie są w pełni uznawane i respektowane, a co więcej - mogą oni doświadczać dodatkowych cierpień $\mathrm{z}$ powodu uczestniczenia w postępowaniu karnym przeciwko sprawcom. Założony cel ma zostać osiągnięty poprzez rozbudowanie i uszczegółowienie postanowień Deklaracji z uwzględnieniem istotnych zmian, jakie nastąpiły od chwili jej uchwalenia, jak też pojawienia się w tym czasie nowych potrzeb.

Merytoryczne unormowania projektu zostały pogrupowane w czterech częściach: I. Postanowienia ogólne (art. 1-4), II. Prawa i obowiązki (art. 5-11), III. Implementacja, monitorowanie i współpraca (art. 12-16) oraz IV. Postanowienia końcowe (art. 17-25). Przedmiotem uwagi w tym miejscu są propozycje zamieszczone w części II., a dla zapewnienia przejrzystości analizy rozpocząć należy od przedstawienia definicji podstawowych pojęć omawianego dokumentu.

\section{Definicje}

Na wstępie projekt precyzuje trzy pojęcia, a mianowicie: ofiara, świadek i ekspert. Już to dowodzi, że Konwencja - inaczej niż Deklaracja,

9 http://www.tilburguniversity.nl/intervict/undeclaration lub http://www.worldsocietyofvictimology.orgindex.html

10 Por. Draft. UN Convention on Justice and Support for Victims of Crime and Abuse of Power, 8 February 2010, http://www.worldsocietyofvictimology.org/publications/Draft/20\%Convention.pdf(jeżeli strona nie działa, należy wpisać pełną nazwę projektu w języku angielskim); syntetycznie o tym dokumencie E. BIEŃKowsKA, Standardy ochrony... 
która definiowała wyłącznie pierwszy z tych terminów - ma mieć na uwadze, choć głównie oczywiście ofiary, to jednak nie tylko .

W ujęciu jego art. 1 ust. 1 ofiarami są osoby fizyczne, które indywidualnie lub zbiorowo doznały krzywdy obejmującej pokrzywdzenie fizyczne lub psychiczne, cierpienie emocjonalne lub stratę ekonomiczną albo pogwałceń fundamentalnych praw w wyniku wiktymizacji, których źródłem - w myśl art. 2 - są działania lub zaniechania stanowiące: a) naruszenia prawa karnego Państw-Stron; b) nadużycia władzy rozumiane jako działania lub zaniechania, które nie są pogwałceniami krajowego prawa karnego, lecz norm uznanych ius cogens na forum międzynarodowym; c) akty terroryzmu, zdefiniowane jako takie w instrumentach międzynarodowych dotyczących terroryzmu, mające spowodować śmierć lub ciężkie uszkodzenie ciała cywili i osób niewalczących albo uszkodzenie mienia, jeżeli akty takie mają na celu zastraszenie ludności albo zmuszenie rządu lub organizacji międzynarodowej do podjęcia lub zaniechania określonej czynności; d) akty handlu ludźmi, jeżeli dotyczą one osób, które zostały porwane, zmuszone lub oszukane i znalazły się daleko od swoich domów i społeczności za obietnicą legalnego zatrudnienia, a faktycznie w celu wykorzystywania seksualnego, przymusowej prostytucji, przymusowej pracy, spłaty długów lub niewolnictwa.

Wskazuje się (art. 1 ust. 2), że dana osoba jest ofiarą niezależnie od tego, czy przestępstwo zostało zgłoszone policji oraz czy sprawca został zidentyfikowany, ujęty, oskarżony lub skazany, jak również niezależnie od więzi rodzinnej łączącej ją ze sprawcą. Pojęcie „ofiara” obejmuje także, jeśli jest to stosowne, bliską rodzinę lub zstępnych bezpośredniej ofiary, jak i osoby, które ucierpiały udzielając ofierze pomocy lub chcąc zapobiec wiktymizacji.

W projekcie zatem - inaczej niż w Deklaracji, która wprowadza odrębną definicję pojęcia „ofiara przestępstwa” (część A. pkt 1.) i pojęcia „ofiara nadużycia władzy” (część B. pkt 18.) - znalazła się definicja pojęcia „ofiara” wspólna dla wszystkich bez względu na źródło ich wiktymizacji. Znacznie precyzyjniej zostały też określone zdarzenia, których wynikiem jest pokrzywdzenie. Zabrakło natomiast wymogu niedyskryminacji, który zawiera pkt 3. części A. Deklaracji. Można jednak uznać, 
że jego wprowadzenie nie jest konieczne, skoro zakaz taki wprowadzają wszystkie dokumenty poświęcone uniwersalnym prawom człowieka.

W myśl art. 1 ust. 3 projektu świadkiem jest osoba wezwana do sądu lub przez inny organ do złożenia zeznań, a ekspert to osoba, która - ze względu na swoje specjalistyczne przeszkolenie, szczególną wiedzę lub doświadczenie - pomaga systemowi prawnemu (ust. 4 tego przepisu).

\section{PraWA I OBOWIĄZKI}

1) Jednakowe prawa dla wszystkich ofiar

Projekt - wprowadzając jedną definicję pojęcia „ofiara” - przewiduje w konsekwencji takie same uprawnienia dla wszystkich spośród nich. Nie różnicuje zatem, jak ma to miejsce w Deklaracji, sytuacji ofiar w zależności od tego, co spowodowało ich pokrzywdzenie. Za punkt wyjścia w tym zakresie przyjmuje te regulacje Deklaracji, które odnoszą się do ofiar przestępstw (część A. pkt 4.-17.), bowiem zamieszczone $\mathrm{w}$ niej unormowania dotyczące ofiar nadużyć władzy są bardzo ograniczone i niewiele mówiące (część B. pkt 19.-21.). Taki stan rzeczy jest następstwem sprzeciwu mocarstw wobec przyznania ofiarom nadużyć władzy takich samych jak ofiarom przestępstw uprawnień, co przewidywał projekt Deklaracji ${ }^{11}$. Twórcy projektu Konwencji wracają więc do pierwotnej koncepcji.

2) Dostęp do wymiaru sprawiedliwości i właściwe traktowanie

Część II. projektu dotyczącą praw i obowiązków inicjuje prawo do dostępu do wymiaru sprawiedliwości i do właściwego traktowania (art. 5), przy czym niektóre z elementów tego uprawnienia zostały następnie rozwinięte $\mathrm{w}$ dalszych przepisach.

Na Państwach-Stronach ma ciążyć obowiązek zagwarantowania, aby ofiary miały dostęp do mechanizmów wymiaru sprawiedliwości

11 Por. E. Bieńkowska, Ofiara i system wymiaru sprawiedliwości, [w:] Problematyka przestępczości na VII Kongresie Narodów Zjednoczonych, red. B. HoŁYst, Warszawa 1987, s. 49 i n.; EAdem, Wiktymologia. Koncepcje..., s. 66. 
i mechanizmów pozwalających na uzyskanie rekompensaty, które powinny być szybkie, sprawiedliwe, tanie i łatwo dostępne. Prawo wewnętrzne ma to zapewniać poprzez mechanizmy sądowe i administracyjne umożliwiające ofiarom uzyskanie rekompensaty, a jeśli w danym przypadku są one właściwe - także poprzez nieformalne mechanizmy rozwiązywania konfliktów, jak mediacja, arbitraż czy praktyki zwyczajowe, ułatwiające pojednanie oraz uzyskanie przez ofiary wyrównania szkód i krzywd. Prawo krajowe ma również przewidywać obowiązek informowania ofiar o prawie do uzyskania rekompensaty na drodze tych mechanizmów (ust. 1).

Państwa powinny ponadto doprowadzić do tego, aby wszystkie takie mechanizmy były odpowiednio uwrażliwione na potrzeby ofiar, czemu ma służyć: przesłuchanie ofiary w rozsądnym czasie w celu określenia jej prawa do rekompensaty za doznane przez nią w wyniku wiktymizacji krzywdy, straty lub szkody bez uszczerbku dla praw oskarżonego; dopuszczenie przedstawienia przez ofiarę jej poglądów i życzeń na tym etapie postępowania, na którym rozpatrywane są kwestie dotyczące jej osobistych interesów bez uszczerbku dla praw oskarżonego i zgodnie z krajowym systemem wymiaru sprawiedliwości karnej; dopuszczenie wyrażenia poglądów przez samą ofiarę albo jej przedstawiciela prawnego lub inną osobę bez uszczerbku dla swobodnego uznania sędziowskiego i zgodnie z krajowym systemem wymiaru sprawiedliwości karnej; szybki zwrot ofierze, jeśli nie jest już potrzebna na użytek śledztwa, jej własności zabranej lub odzyskanej przez policję lub inny organ; przyznanie ofiarom, gdzie to właściwe, prawa do zaskarżenia decyzji o nieściganiu w sprawach dotyczących ich wiktymizacji; zapewnienie ofiarom odpowiedniej pomocy w trakcie postępowania nieformalnego, administracyjnego i karnego; podjęcie - gdy jest to niezbędne - środków minimalizujących niedogodności dla ofiar i chroniących ich prywatność; zapewnienie ochrony przed zastraszaniem i zemstą ofiarom, członkom ich rodzin i świadkom oskarżenia; unikanie zbędnych opóźnień w rozpatrywaniu spraw i wykonaniu orzeczeń na rzecz ofiar; zapewnienie, aby orzeczenia takie nabrały mocy prawnej (ust. 2). 
I wreszcie, w ust. 3 art. 5 projektu jest mowa o zwrocie ofiarom i świadkom ich uzasadnionych wydatków poniesionych w związku $\mathrm{z}$ koniecznością uczestniczenia $\mathrm{w}$ postępowaniu.

Zakres przedstawionego unormowania wykracza poza zagadnienia objęte przedmiotowym uprawnieniem ofiar w Deklaracji (pkt 4-7 części A.). W szczególności Deklaracja pomija prawo do zaskarżenia decyzji o nieściganiu, do wypowiadania się za pośrednictwem przedstawiciela oraz do zwrotu własności, jak również prawo do zwrotu wydatków.

$\mathrm{W}$ art. 5 projektu dwukrotnie podkreślono, że korzystanie przez ofiarę z określonego uprawnienia nie może godzić w prawa oskarżonego, a zastrzeżenie tego rodzaju znajduje się również w Deklaracji (pkt 6 lit. b) części A.), jak też w Preambule (pkt 12) i kilku przepisach (art. 18, 20 i 23) dyrektywy 2012/29/UE. Na tle takich regulacji ujawnia się problem, jaki powstał z chwilą, gdy ofiary uzyskały określone prawa, w tym zwłaszcza prawa przysługujące im w postępowaniu karnym. Jest to kwestia wzajemnej relacji między prawami procesowymi ofiary i sprawcy przestępstwa. Istota rzeczy sprowadza się do tego, że określone prawa procesowe sprawców, a wśród nich - prawo do rzetelnego procesu, stanowią fundamentalne prawa człowieka. Korzystanie przez ofiary z ich uprawnień może zaś w nie godzić. Procesowe prawa ofiar nie figurują przy tym w katalogu praw człowieka, jak też nie można ich bezpośrednio z praw człowieka przysługujących sprawcom wywieść. Mają one więc niższą rangę i dopóki nie uzyskają takiej samej jak prawa sprawców, dopóty ofiary będą znajdować się w gorszej sytuacji procesowej ${ }^{12}$.

3) Ochrona ofiar, świadków i ekspertów

Deklaracja jedynie bardzo ogólnie mówi o potrzebie ochrony ofiar i ich rodzin oraz świadków przez zastraszaniem i odwetem (pkt 6 lit. d) części A.). Odpowiadający tej regulacji przepis art. 6 projektu Konwencji jest ujęty szerzej, jak też wyraźnie konkretniej.

Wskazuje się, że Państwa-Strony powinny podejmować odpowiednie środki w ramach krajowych systemów prawnych mające na celu ochronę integralności fizycznej, psychologicznej i społecznej, godności

12 Szerzej E. Bieńkowska, Standardy ochrony... (wraz z cyt. literaturą przedmiotu). 
oraz prywatności ofiar, świadków i ekspertów przed potencjalną zemstą lub zastraszaniem, a w odpowiednich przypadkach - także ich krewnych i innych osób blisko z nimi związanych (ust. 1). Środkami takimi mogą być: a) procedury ochrony fizycznej, jak utajnienie lub ograniczenie jawności informacji o ich tożsamości i miejscu pobytu, zmiana miejsca pobytu, zmiana tożsamości i inne środki niezbędne dla zapewnienia ochrony; b) zasady dowodowe umożliwiające złożenie zeznań w sposób gwarantujący bezpieczeństwo, jak dopuszczenie ich złożenia za pośrednictwem technologii komunikacyjnych (video i inne); oraz c) uzgodnienie lub zaaranżowanie z innym Państwem-Stroną przesiedlenia (ust. 2).

Dla celów ochrony osobistej najbardziej zagrożonych ze strony sprawców i osób z ich najbliższego otoczenia ofiar, świadków i ekspertów mogłyby zatem znajdować zastosowanie nawet dość radykalne środki całkowicie zmieniające ich dotychczasowe życie. W projekcie podkreśla się jednak, iż miałoby to być jedynie pewną ostatecznością („to the extent necessary and feasible" - art. 6 ust. 2 lit. a).

4) Informowanie

Przepis art. 7 projektu Konwencji wprowadza bardzo rozbudowaną regulację dotyczącą prawa ofiary do uzyskiwania informacji. Ujęty jest on zdecydowanie szerzej niż odpowiadający mu pkt 6 lit. a) części A. Deklaracji, w którym ogólnie jest mowa o informowaniu ofiar o ich roli i zakresie przysługujących im uprawnień oraz terminach, toku postępowania i podejmowanych decyzjach, „Zwłaszcza gdy w grę wchodzą poważne przestępstwa i ofiary domagają się takich informacji”.

W myśl ust. 1 wskazanego przepisu projektu Państwa-Strony mają zapewnić przyznanie ofiarom prawa do informacji od chwili pierwszego kontaktu z właściwym organem, o którym to uprawnieniu muszą zostać poinformowane. Ofiary powinny otrzymać ogólną informację przekazaną im w możliwie najszybszy i najskuteczniejszy sposób właściwy dla danej kultury, a więc ustnie lub pisemnie $z$ uwzględnieniem umiejętności czytania i pisania oraz wymogów tradycji. Natomiast specjalne informacje powinny zostać przekazane ofierze osobiście wsposób ułatwiający jej ich zrozumienie. Powinny one dotyczyć przynajmniej takich kwestii, jak: rodzaj służb lub organizacji, do jakich mogą się zwrócić 
o wsparcie; rodzaj wsparcia, jakie mogą uzyskać łącznie z dostępem do służb zdrowia i pomocy socjalnej oraz innej niezbędnej pomocy; gdzie i w jaki sposób mogą zgłosić przestępstwo; tryb postępowania po złożeniu zawiadomienia o przestępstwie $\mathrm{i}$ ich rola $\mathrm{w}$ tym postępowaniu; ich rola oraz uprawnienia, etapy i postępy w sprawie oraz podejmowane w niej decyzje, zwłaszcza wtedy, gdy w grę wchodzą poważne przestępstwa i ofiary życzą sobie informacje takie uzyskiwać; w jaki sposób i na jakich warunkach mogą uzyskać ochronę; w jakim zakresie i kiedy przysługuje im dostęp do porady i pomocy prawnej; wymogi dotyczące uzyskania rekompensaty; w odniesieniu do ofiar mieszkających $\mathrm{w}$ innym Państwie - dostępne dla nich specjalne instrumenty ochrony ich interesów; i w końcu - gdzie i jak można uzyskać więcej informacji.

$\mathrm{Na}$ życzenie ofiar ma im zostać zapewnione otrzymywanie informacji o skutku złożonej skargi, warunkach umożliwiających im zapoznanie się z przebiegiem postępowania w przypadku oskarżenia oraz o wyroku sądu (ust. 2). Państwa-Strony powinny też podjąć niezbędne środki, aby zapewnić - przynajmniej wówczas, gdy może to wywoływać zagrożenie dla niej-powiadomienie ofiary o zwolnieniu aresztowanego lub skazanego sprawcy (ust. 3). Mogą one ponadto z własnej inicjatywy zapewnić, aby ofiary miały prawo do nieotrzymywania informacji o toku sprawy i jej wyniku oraz zwolnieniu sprawcy, chyba że ich przekazanie jest obligatoryjne stosownie do wymogów postępowania karnego (ust. 4).

5) Pomoc

Kolejny przepis art. 8 projektu określa prawo ofiary do pomocy. Państwa-Strony powinny zapewnić ofiarom niezbędną pomoc materialną, medyczną, psychologiczną i socjalną ze środków państwowych, dobrowolnych i lokalnych niesioną przez agencje lub programy zgodnie z prawem lub normami krajowymi (ust. 1). Mają one zachęcać do rozwijania sieci wymiaru sprawiedliwości karnej, pomocy społecznej, służby zdrowia i zdrowia psychicznego, usług pomocy dla ofiar oraz innych odpowiednich grup czy instytucji w celu ułatwienia przekazywania do nich ofiar oraz koordynowania i planowania działań w zakresie pomocy dla ofiar (ust. 2). Powinny także zachęcać do tworzenia lokalnych i regionalnych centrów pomocy dla ofiar koordynujących funkcjonowanie 
sieci, służących rozwijaniu i dokonywaniu przekazywań, jak też - w razie potrzeby - dostarczających ofiarom bezpośredniej pomocy (ust. 3). Zadaniem Państw-Stron jest również ułatwianie przekazywania ofiar przez policję i inne organy do centrów pomocy dla ofiar lub służb (ust. 4).

Państwa-Strony powinny dążyć do zapewnienia trzech rodzajów pomocy: natychmiastowej, średnio- oraz długoterminowej. Pierwsza z nich polega na: a) wezwaniu pomocy medycznej zarówno pierwszej, jak i ratunkowej oraz towarzyszeniu ofierze w trakcie transportu i badania, a służby wsparcia zawsze powinny zostać wezwane w przypadku badania specjalistycznego lub śmierci; b) wsparciu materialnym, jak zapewnienie miejsca w schronisku, noclegu, transportu czy naprawa zniszczonego mienia; c) interwencji kryzysowej łącznie z doradztwem w sytuacji kryzysowej i rozwiązywaniem problemu; d) poinformowaniu i powiadomieniu o tym, co się wydarzyło w takim zakresie, w jakim nie godzi to $\mathrm{w}$ przebieg śledztwa, $\mathrm{z}$ uwzględnieniem powiadomienia o bezpośrednich obowiązkach wobec systemu wymiaru sprawiedliwości karnej, a pomoc taka powinna zostać również zaoferowana przy powiadamianiu rodziny i przyjaciół; e) ochronie przed ponowną wiktymizacją poprzez uruchomienie środków bezpieczeństwa, co może obejmować informację o obserwacji policyjnej, zmianie miejsca pobytu, natychmiastowym kontakcie, jak również pomoc w uzyskaniu sądowego nakazu ochrony; f) ochronie przed mediami; g) ogólnym wsparciu przy kontaktach z instytucjami pomocy społecznej, wymiaru sprawiedliwości i służby zdrowia oraz reagowaniu na pilne potrzeby; jak też h) zapewnieniu w najwyższym możliwym stopniu poufności i prywatności (ust. 6 lit. A.).

Z kolei pomoc średnioterminowa to: a) kontynuowanie środków zastosowanych $\mathrm{w}$ ramach pomocy natychmiastowej; b) interwencje o charakterze psychospołecznym, które mogą obejmować poradnictwo pourazowe, terapię w zakresie zdrowia psychicznego, poradnictwo rodzinne, poradnictwo duszpasterskie lub tradycyjne praktyki tego rodzaju; c) pomoc w zaspokojeniu potrzeb finansowych lub wypełnieniu wniosków i wspieranie przy ubieganiu się o kompensatę, restytucję, ubezpieczenie albo zasiłek; d) pomoc prawna w sprawach karnych i cywilnych, która w możliwie największym stopniu powinna być bezpłatna; 
oraz e) informacja, wsparcie i pomoc w odniesieniu do opcji alternatywnego wymiaru sprawiedliwości (ust. 6 lit. B.).

I w końcu, pomoc długoterminowa polega na kontynuowaniu wcześniej podjętych środków pomocy natychmiastowej i średnioterminowej, jak też zapewnieniu lub przywróceniu ofierze pozycji w rodzinie, społeczności lokalnej oraz miejscu nauki i pracy (ust. 6 lit. C.).

$\mathrm{W}$ art. 6 ust. 5 projektu jest jeszcze mowa o szczególnej kwestii, jaką stanowi pomoc językowa. Wskazuje się, że w razie potrzeby skorzystania z pomocy tłumacza, powinna nim być osoba przeszkolona w odniesieniu do problemów dotyczących ofiar, a przedstawiciele służb wspierania ofiar powinni znać używaną terminologię.

Projekt reguluje kwestię pomocy dla ofiar znacznie precyzyjniej niż czyni to Deklaracja. Pomija jednak - a wydaje się, że szkoda - problem odpowiedniego szkolenia wszystkich osób stykających się z ofiarami, dzięki czemu możliwe jest wyczulenie tych osób na potrzeby ofiar, o czym jest mowa w pkt 16. części A. Deklaracji. Nie wskazuje też, jak czyni to Deklaracja w pkt 17. części A., na konieczność wzmożonej troski o ofiary zaliczane w wiktymologii do kategorii szczególnie wrażliwych za względu na swoje charakterystyki osobiste i typ doznanej wiktymizacji.

\section{6) Sprawiedliwość naprawcza}

Deklaracja stanowi, że „Mechanizmy nieformalne służące rozwiązaniu konfliktu, jak mediacja, rozjemstwo i wymiar sprawiedliwości zwyczajowej albo praktyki miejscowe, powinny być - gdzie jest to stosowne - wykorzystane $\mathrm{w}$ celu ułatwienia pojednania i uzyskania zadośćuczynienia dla ofiar" (część A. pkt 7.) ${ }^{13}$. Projekt przewiduje natomiast $\mathrm{w}$ art. 9, że Państwa-Strony powinny zachęcać we właściwych przypadkach do utworzenia lub wzmocnienia systemów sprawiedliwości naprawczej mających za swój priorytet ochronę interesów ofiar, jak też podkreślać potrzebę zaakceptowania przez przestępcę jego odpowiedzialności za przestępstwo i uznania negatywnych skutków

13 Por. bliżej E. BıEŃkowska, Wdrażanie instrumentów sprawiedliwości naprawczej, [w:] Mediacja w praktyce prokuratorskiej - dziś i jutro, pod red. L. MAzowieckieJ, Warszawa 2012, s. 22 i n. 
przestępstwa dla ofiary w postaci aktu poważnych przeprosin (ust. 1). Powinny one ponadto zapewnić, aby ofiary miały możliwość wyboru, lub nie, programów sprawiedliwości naprawczej na podstawie swoich praw wewnętrznych, a jeśli zdecydują się je wybrać, mechanizmy te muszą zapewniać ofiarom poszanowanie godności, współczucie oraz podobne prawa i usługi jak określone wKonwencji ${ }^{14}$.

W proponowanym ujęciu na czoło zostało wysunięta ta cecha, która jest najbardziej charakterystyczna dla sprawiedliwości naprawczej, a mianowicie - ma ona służyć w pierwszej kolejności ochronie interesów i zaspokojeniu potrzeb ofiary. Przyjęcie takiego rozwiązania pozostaje w zgodzie z wypracowanymi na forum ONZ Podstawowymi zasadami Narodów Zjednoczonych dotyczącymi stosowania programów sprawiedliwości naprawczej w sprawach karnych z dnia 25 lipca 2002 r. $^{15}$ Zwrócić trzeba też uwagę, że projekt ma na uwadze nie tylko mediację, która jest w praktyce najczęściej stosowanym programem sprawiedliwości naprawczej, lecz także pozostałe jej mechanizmy ${ }^{16}$, co odzwierciedla fakt, że sprawiedliwość naprawcza już na dobre wkroczyła do polityki karnej, jak też uznana została za skuteczną i godną propagowania opcję.

7) Restytucja obejmująca reparację

Już sam tytuł art. 10 „Restytucja obejmująca reparację” projektu Konwencji dowodzi, że kwestia ta została ujęta w nim szerzej niż w Deklaracji, która ogranicza się do samej restytucji (część A. pkt 8.). Przepis ten stanowi w ust. 1, że Państwa-Strony powinny wprowadzić regulacje czyniące przestępców odpowiedzialnymi za zapłatę restytucji

14 Por. też E. Bieńkowska, Wdrażanie instrumentów..., s. 25 i n.

15 Por ECOSOC Res. 2002/12: United NationsBasic Principles on the Use of Restorative Justice Programmes in Criminal Matters, m. in. w: Y. Dandurand, C. T. Griffiths, Handbook on Restorative Justice Programmes, Criminal Justice Handbook Series, United Nations, New York 2006, Annex II, s. 99-102; szerzej E. BıEŃKowskA, Wdrażanie instrumentów..., s. 26 i n.

16 Dokładniej o poszczególnych programach w polskiej literaturze przedmiotu zwłaszcza W. Zalewski, Sprawiedliwość naprawcza - początek ewolucji polskiego prawa karnego?, Gdańsk 2006, s. 184 i n.; por. też A. SzymiŁo-KulczyckA, Proces karny a idea sprawiedliwości naprawczej, [w:] System prawa karnego procesowego, I.2: Zagadnienia ogólne, pod red. P. Hofmańskiego, Warszawa 2013, s. 304 i n. 
ofiarom, ich rodzinom lub zstępnym, a składać się na nią powinien zwrot własności lub zapłata za doznaną krzywdę lub stratę, zwrot wydatków poniesionych $\mathrm{w}$ następstwie wiktymizacji, jak również - jeśli jest to właściwe - poważne przeprosiny oraz dostarczenie usług i przywrócenie praw. Mają one - stosownie do ust. 2 - dokonać przeglądu swoich praktyk, regulacji, ustaw i konstytucji w celu zapewnienia, aby restytucja mogła zostać orzeczona w wyroku wydanym w sprawie karnej.

W przypadku przestępstw wymierzonych w środowisko prawnie dozwolone powinno być zasądzenie restytucji w postaci jego odbudowania, rekonstrukcji infrastruktury, wymiany urządzeń oraz zwrotu wydatków związanych z przeniesieniem się wtedy, gdy krzywda skutkuje przesiedleniem społeczności (ust. 3). Jeżeli natomiast naruszenia krajowego prawa karnego dopuścili się funkcjonariusze publiczni lub inne osoby działające w charakterze funkcjonariuszy lub quasi-funkcjonariuszy, Państwa-Strony powinny zapewnić restytucję dla ofiar od tego Państwa, którego funkcjonariusze byli odpowiedzialni za krzywdę, a wówczas, gdy rząd, podczas kadencji którego miały miejsce wiktymizujące działania lub zaniechania, już nie istnieje, restytucję dla ofiar powinno zapewnić Państwo lub rząd będący sukcesorami (ust. 4).

Dalsze unormowania art. 10 projektu nie mają już swoich odpowiedników w Deklaracji, a są one ważne. Stanowią, że w razie wydania nakazu restytucyjnego Państwo-Strona ma być odpowiedzialne za nadanie mu mocy prawnej (ust. 5), jeśli zaś przestępca został prawnie zobowiązany do zapłaty restytucji i innych sankcji pieniężnych, pierwszeństwo ma przysługiwać restytucji (ust. 6). Odnosząc się natomiast do sytuacji, gdy ofiara dochodzi restytucji na drodze cywilnej, zaznaczono, iż Państwo ma zachęcać do usprawnienia takiego postępowania i minimalizowania jego kosztów (ust. 7).

8) Kompensata

Ostatnim uprawnieniem ofiar przewidzianym w projekcie Konwencji jest prawo do kompensaty od państwa ${ }^{17}$. Stosownie do jego art. 11

17 Por. też E. Bieńkowska, L. Mazowiecka, Państwowa kompensata przysługująca ofiarom niektórych przestępstw. Komentarz, Warszawa 2011, s. 50 i n. 
państwowa kompensata finansowa powinna przysługiwać - jeśli nie jest możliwa restytucja od przestępcy lub z innych źródeł - ofiarom, które doznały poważnej krzywdy cielesnej albo uszczerbku w zdrowiu fizycznym lub psychicznym w następstwie umyślnego przestępstwa $\mathrm{z}$ użyciem przemocy oraz członkom rodzin ofiar, które w wyniku takiego przestępstwa poniosły śmierć albo stały się niepełnosprawne fizycznie lub psychicznie (ust. 1). Powinna ona obejmować pokrycie kosztów leczenia i rehabilitacji, a należy rozważyć, aby dotyczyła też wydatków pogrzebowych, utraty dochodów i źródła utrzymania, jak również bólu i cierpienia oraz innych krzywd psychicznych (ust. 2 i 3). Odnotować należy, że Deklaracja (część A. pkt 12.-13.) nie precyzuje, co ma obejmować kompensata od państwa.

Państwa powinny popierać tworzenie, wzmacnianie i poszerzanie krajowych, regionalnych i lokalnych funduszy kompensowania ofiar oraz rozważyć kwestię ich finansowania ze swojego budżetu, specjalnych podatków, grzywien, dotacji prywatnych oraz z innych źródeł (ust. 4). Fundusze takie powinny gwarantować sprawiedliwą, odpowiednią i we właściwym czasie wypłacaną kompensatę, jak i przewidywać ją w nagłych sytuacjach krytycznych oraz jako mającą charakter przejściowy. Muszą one być łatwo dostępne, co wymaga przede wszystkim stałego prowadzenia szeroko zakrojonej akcji informowania o prawie do kompensaty iwarunkach jej uzyskania (ust. 5).

Wskazuje się ponadto, a takich regulacji Deklaracja nie zawiera, że w odpowiednich przypadkach powinny być tworzone również fundusze innego rodzaju wchodzące w grę zwłaszcza wówczas, gdy Państwo, którego obywatelem jest ofiara, nie jest w stanie jej skompensować (ust. 6). W sytuacjach transgranicznych natomiast cudzoziemcowi powinno wypłacać kompensatę - na zasadzie wzajemności - to Państwo, na terytorium którego zostało popełnione przestępstwo (ust. 7). 


\section{Podsumowanie i konkluzja - CZy Konwencja Jest POTRZEBNA?}

Czy Konwencja w projektowanym brzmieniu rzeczywiście wprowadza wyższe standardy i tym samym mogłaby sprawić, że sytuacja ofiar ulegnie dalszej znaczącej poprawie, do czego nie jest już w stanie doprowadzić Deklaracja o podstawowych zasadach sprawiedliwości, a zatem czy w ogóle jest potrzebna? - pytanie to jest jak najbardziej zasadne, ponieważ także w środowisku samych wiktymologów nie ma pełnej zgody co do celowości przyjęcia przez ONZ nowego instrumentu ochrony ofiar. Wskazuje się w tym zakresie głównie na to, że proces negocjacji nad projektem konwencji i jego przyjęciem jest długotrwały, a poszczególnestadia zajmą lata, w tym czasie zaś nic więcej nie będzie się działo na forum ONZ $\mathrm{w}$ odniesieniu do podniesienia poziomu przestrzegania standardów praw ofiar. Podkreślano też, że przyjęcie konwencji jest możliwe pod warunkiem, że większość państw z najróżniejszych regionów świata zgodzi się co do jej istoty, a nie jest wykluczone, że w takiej sytuacji uzyskanie konsensusu będzie wymagało obniżenia wprowadzonych już standardów. Z kolei zwolennicy konwencji operują następującymi argumentami: jej przyjęcie podniesie świadomość problemów dotyczących ofiar; konwencja jako instrument stanowiący tzw. twarde prawo międzynarodowe wywrze silniejszą presję na rządy poszczególnych państw niż Deklaracja jako prawo miękkie, niewiążące; sądy będą traktowały konwencję poważniej niż Deklarację; konwencja daje podstawę do analizy prawa wewnętrznego; proces ratyfikacyjny zmusi państwa, które nie zgodziły się na nią, do oficjalnego wyjaśnienia, dlaczego nie wspierają praw ofiar w takim zakresie, w jakim wymaga tego konwencja; i w końcu - skoro Narody Zjednoczone przyjęły już Konwencje dotyczące materii ze sfery prawa karnego, to tym samym ranga i znaczenie Deklaracji zdecydowanie zmalały ${ }^{18}$.

18 Szerzej M. Groenhuijsen, The Draft UN Convention on Justice and Support for Victims of Crime and Abuse of Power, with special reference to its provisions on restorative justice, s. 2-3; http://arno.uvt.nl/show.cgi?fid=94932 
Niezależnie od wskazanych kwestii należy zwrócić uwagę na jeszcze jeden ważny aspekt. Być może bowiem konwencja nie jest aż tak bardzo potrzebna $\mathrm{w}$ sytuacji, gdy dokumenty regionalne regulują, zwłaszcza z mocą wiążącą, zagadnienia, które już są lub dopiero mają być jej przedmiotem. Inaczej jest jednak wówczas, gdy tak nie jest. Wtedy jedynym instrumentem motywującym do podjęcia określonych działań w danej dziedzinie jest wyłącznie akt prawny Narodów Zjednoczonych. Projekt Konwencji wykracza zaś niekiedy -jak wskazywałam - poza standardy Deklaracji. Co więcej, także w przypadku istnienia standardów regionalnych jest możliwe, że w konwencji znajdą się rozwiązania im nieznane, bowiem przejęte $\mathrm{z}$ prawa i praktyki państw spoza danego regionu. Tak właśnie jest w przypadku dokumentów europejskich. Choć bowiem twórcy omawianego projektu Konwencji wyraźnie wskazują, że przy jego opracowywaniu mieli na uwadze rekomendację Rec (2006)8 Komitetu Ministrów Rady Europy w sprawie pomocy dla ofiar przestępstw z dnia 14 czerwca 2006 r. ${ }^{19}$, która jest również nie bez znaczenia dla kształtowania standardów unijnych, to z drugiej strony w projekcie znalazły się pewne rozwiązania nieznane nie tylko tej rekomendacji, ale w ogóle prawu europejskiemu, a zwłaszcza niewprowadzone do wspominanej dyrektywy 2012/29/UE ${ }^{20}$.

Najistotniejsze $\mathrm{w}$ moim przekonaniu jest, że projekt znacznie szerzej traktuje problem zrekompensowania ofierze przez sprawcę szkód i krzywd wyrządzonych przestępstwem, a przede wszystkim, że jest

19 Recommendation on the Assistance to Victims of Crime, [w:] Victims of Crime Support and Assitance, Council of Europe, Strasbourg 2006, s. 71-82 (tekst polski w: E. Bieńkowska, L. Mazowiecka, Ofiara przestępstwa..., s. 119-131); szerzej E. BieńKowsKA, Rada Europy o pomocy dla ofiar przestęstw kompleksowo, "Zeszyty Prawnicze Wyższej Szkoły Zarządzania i Prawa im. Heleny Chodkowskiej w Warszawie» $2(35) / 2010$, s. 115 i n.

20 Dz.Urz.UE L 315 z 14.11.2012, s. 57; szerzej zwłaszcza E. BieńkowskA, K. DudKA, C. Kulesza, L. Mazowiecka, P. Starzyński, W. Zalewski, E. Zielińska, Dyrektywa Parlamentu Europejskiego i Rady 2012/29/UE ustanawiajaca normy minimalne w zakresie praw, wsparcia i ochrony ofiar przestępstwa. Komentarz, pod red. E. BieńkowsKieJ, L. Mazowieckiej, Warszawa 2014, s. 13 i in.; też E. Bieńkowska, Ofiary przestępstw w postępowaniu karnym - nowe standardy Unii Europejskiej, «PiP» 69.4/2014, s. 58 i n.; EADEM, Standardy ochrony... 
w nim mowa również o przyznaniu orzeczeniom na rzecz ofiary pierwszeństwa w zakresie egzekucji przed innymi sankcjami o charakterze finansowym. W przypadku braku takiego unormowania zwykle się okazuje, że gdy ma dojść do zaspokojenia ofiary, sprawca jest już niewypłacalny. Ofiara staje się więc na ogół klientem państwowych systemów kompensacyjnych, o ile oczywiście spełnia kryteria uprawniające ją do ubiegania się o kompensatę. Jeśli nie, może pozostać po prostu z niczym. Dzięki proponowanej w projekcie regulacji interesy ofiary byłyby zatem zdecydowanie lepiej chronione. Jednocześnie zaś zmalałaby liczba osób ubiegających się o kompensatę od państwa, a wiadomo, że podejmuje się wszelkie możliwe kroki, aby zobowiązania państwa $\mathrm{z}$ tego tytułu minimalizować.

Na uwagę zasługują niektóre z projektowanych rozwiązań odnoszących się do pomocy dla ofiar. Dotyczy to zwłaszcza kwestii rodzajów pomocy, jakie powinny być dostępne dla ofiar. Długość okresu niezbędnego do udzielenia skutecznej pomocy może być podstawą wyróżniania służb reagowania natychmiastowego i takich, których działania muszą przez jakiś, krótszy lub dłuższy, czas trwać. Niezbędna jest w tym zakresie pewna specjalizacja, co powinno się uwzględniać już przy budowaniu sieci pomocy dla ofiar. Godne odnotowania jest również to, że zwrócono uwagę na konieczność obecności służb wsparcia w chwili informowania najbliższych ofiary o zdarzeniu, które było jej udziałem, zwłaszcza wówczas, gdy jego skutki są bardzo tragiczne. Osoby najbliższe dla ofiary, szczególnie w przypadku jej śmierci, z racji ich niezwykle traumatycznych przeżyć i płynącymi stąd poważnymi trudnościami w wyjściu z sytuacji kryzysowej uważa się bowiem za tę grupę, która wymaga o wiele intensywniejszej terapii i bardziej nasilonej troski niż ma to miejsce w innych przypadkach.

Nie sposób nie odnieść się również do kwestii związanych za sprawiedliwością naprawczą. Nie jest niczym nowym promowanie stosowania w ramach polityki karnej programów sprawiedliwości naprawczej ani wskazywanie, że są one zorientowane na ofiarę przestępstwa, a nie na jego sprawcę. Godne podkreślenia jest jednak, że także twórcy projektu Konwencji uznali za niezbędne kwestie te wyeksponować. Praktyka dowodzi bowiem, że nierzadko sprawiedliwość naprawcza 
postrzegana jest jako służąca wyłącznie resocjalizacji sprawcy. Wiadomo też powszechnie, że prawników cechuje głęboko zakorzeniona awersja do akceptowania jakichkolwiek nowości, a koncepcja sprawiedliwości naprawczej za taką cały czas uchodzi. Wymóg korzystania w sprawach karnych ze wszystkich jej programów, a więc nie tylko z mediacji, wprowadza też dyrektywa 2012/29/UE (art. 12). Konwencja stałaby się zatem kolejnym bodźcem do poważnego zajęcia się tymi kwestiami. Podkreślić też trzeba, że rozwiązanie takie dawałoby możliwość dostosowania do realiów i potrzeb każdego przypadku konkretnego programu sprawiedliwości naprawczej. Wymagałoby to oczywiście odpowiedniego przygotowania i znacznego zaangażowania się osób, w których gestii to leży, w dobór spraw nadających się do przekazania na drogę takiej procedury.

I w końcu, odnieść się należy do regulacji dotyczących ochrony ofiar, świadków i ekspertów. Jak dotąd prawo unijne ma bowiem na uwadze wyłącznie ochronę ofiar i członków ich rodzin, lecz o środkach ich ochrony fizycznej mówi tylko bardzo ogólnikowo (art. 18 dyrektywy 2012/29/UE). Rada Europy poświęciła zaś kwestii ochrony świadków i biegłych tylko niewiążące rekomendacje Komitetu Ministrów, a mianowicie nr R (97)13 odnoszącą się do zastraszania świadków i praw do obrony z dnia 11 września 1997 r. ${ }^{21}$, która ma na uwadze świadków występujących w sprawach o przestępczość zorganizowaną i przestępstwa w rodzinie, oraz Rec (2005)9 o ochronie świadków i osób współpracujących z wymiarem sprawiedliwości z dnia 20 kwietnia 2005 r. ${ }^{22}$, która odnosi się do przestępczości zorganizowanej łącznie z terroryzmem.

Projekt Konwencji nie zawiera żadnych postanowień dotyczących szczególnych kategorii ofiar, lecz adresuje je do wszystkich ich grup. Jest to zapewne wynikiem tego, że regulacje poświęcone niektórym spośród nich już się znalazły w licznych innych dokumentach Narodów Zjednoczonych, jak w szczególności: Konwencja w sprawie zwalczania

21 Recommendation concerning intimidation of witnesses and the rights of defence, [w:] Victims of Crime..., s. 151158 (tekst polski w: E. BiEŃkowska, L. Mazowiecka, Ofiara przestępstwa..., s. 84-90); por. szerzej E. BıEŃкоwsкA, Świadek nie dość chroniony, «Gazeta Sądowa» 9/1998, s. 30 i n.

22 Recommendation on the protection of witnesses and collaborators of justice, [w:] Victims of Crime..., s. 107-114. 
handlu ludźmi i eksploatacji prostytucji z dnia 21 marca 1950 r. $^{23}$. Uzupełniająca Konwencja w sprawie zniesienia niewolnictwa, handlu niewolnikami oraz instytucji i praktyk zbliżonych do niewolnictwa $\mathrm{z}$ dnia 7 września 1956 r. $^{24}$, Międzynarodowa Konwencja w sprawie likwidacji wszelkich form dyskryminacji rasowej z dnia 7 marca 1966 r. $^{25}$, Międzynarodowa Konwencja o zwalczaniu i karaniu zbrodni apartheidu $\mathrm{z}$ dnia 30 listopada $1973 \mathrm{r}^{26}$, Międzynarodowa Konwencja przeciwko apartheidowi w sporcie $\mathrm{z}$ dnia 10 grudnia $1985 \mathrm{r}^{27}$, Konwencja w sprawie likwidacji wszelkich form dyskryminacji kobiet $\mathrm{z}$ dnia 18 grudnia 1979 r. $^{28}$, Deklaracja o eliminacji przemocy wobec kobiet $\mathrm{z}$ dnia 20 grudnia 1993 r. $^{29}$, Konwencja w sprawie zakazu stosowania tortur oraz innego okrutnego, nieludzkiego lub poniżającego traktowania albo karania z dnia 11 grudnia 1984 r. $^{30}$, Protokół fakultatywny do Konwencji w sprawie zakazu stosowania tortur oraz innego okrutnego, nieludzkiego traktowania albo karania z dnia 18 grudnia 2002 r. $^{31}$, Konwencja o prawach dziecka z dnia 20 listopada 1989 r. $^{32}$, Protokół fakultatywny do Konwencji o prawach dziecka w sprawie handlu dziećmi, dziecięcej prostytucji i dziecięcej pornografii z dnia 25 maja 2000 r. $^{33}$, Wytyczne dotyczące wymiaru sprawiedliwości w sprawach, w których ofiarami lub świadkami są dzieci z dnia 22 lipca 2005 r. $^{34}$, Międzynarodowa Konwencja o zwalczaniu finansowania terroryzmu z dnia 9 grudnia

\footnotetext{
23 Dz.U. z 1952 r. Nr 41, poz. 278.

24 Dz.U. z 1963 r. Nr 33, poz. 185.

25 Dz.U. z 1969 r. Nr 25, poz. 187.

26 Dz.U. z 1976 r. Nr 32, poz. 186.

27 Dz.U. z 1988 r. Nr 14, poz. 100.

28 Dz.U. z 1982 r., Nr 10, poz. 71.

29 Res. 48/104, Annex: Declaration on the elimination of violence against women (tekst polski w: E. Bieńkowska, L. Mazowiecka, Ofiara przestępstwa..., s. 323-327).

30 Dz.U. z 1989 r. Nr 63, poz. 378.

31 Dz.U. z 2007 r. Nr 30, poz. 192.

32 Dz.U. z 1991 r. Nr 120, poz. 526 ze zm.

33 Dz.U. z 2007 r. Nr 76, poz. 494.

34 Guidelines on justice in matters involving child victims and witnesses of crime, ECOSOC Res. 2005/20, www.un.org/en/ecosoc/docs/2005/resolution\%202005-20.pdf; tekst polski: wytyczne_ONZ_dziecko_ofiara_przestepstwa[1]pdf
} 
1999 r. $^{35}$, Rzymski statut Międzynarodowego Trybunału Karnego z dnia 17 lipca 1998 r. $^{36}$, Podstawowe zasady i wytyczne Narodów Zjednoczonych w sprawie prawa do zadośćuczynienia i reparacji dla ofiar ciężkich pogwałceń międzynarodowego prawa praw człowieka oraz poważnych naruszeń międzynarodowego prawa humanitarnego $\mathrm{z}$ dnia 16 grudnia 2005 r. $^{37}$, Konwencja przeciwko międzynarodowej przestępczości zorganizowanej z dnia 17 lipca 1998 r. ${ }^{38}$, Protokół o zapobieganiu, zwalczaniu oraz karaniu za handel ludźmi, w szczególności kobietami i dziećmi, uzupełniający Konwencję Narodów Zjednoczonych przeciwko międzynarodowej przestępczości zorganizowanej z dnia 15 listopada $2000 \mathrm{r}^{39}$ (tzw. Protokół z Palermo), Protokół przeciwko przemytowi migrantów drogą lądową, morską i powietrzną, uzupełniający Konwencję Narodów Zjednoczonych przeciwko międzynarodowej przestępczości zorganizowanej z dnia 15 listopada 2000 r. ${ }^{40}$, i w końcu - powoływane już - Wytyczne dotyczące stosowania programów sprawiedliwości naprawczej w sprawach karnych.

Odnosząc się do celowości konwencji o prawach ofiar, uważam, że jest ona potrzebna, i to bardzo. Podjęcie oraz prowadzenie procedury prowadzącej do jej przyjęcia wcale nie musi oznaczać zastopowania na ten okres wszelkich przedsięwzięć Narodów Zjednoczonych służących dalszemu wdrażaniu Deklaracji o podstawowych zasadach sprawiedliwości. Mam na myśli choćby opracowanie w tym czasie różnego rodzaju podręczników czy wytycznych. Konwencja ma bowiem nie tylko zupełnie inną niż Deklaracja rangę, ale niewątpliwie także w znacznie większym stopniu niż Deklaracja zmusza do zwracania uwagi na kwestie będące jej przedmiotem. Ważne jest także, że może z lepszym skutkiem upowszechnić i doprowadzić do wdrożenia rozwiązań oraz dobrych

35 Dz.U. z 2009 r. Nr 263, poz. 2620.

36 Dz.U. z 2003 r. Nr 78, poz. 708 ze zm.

37 Res. 60/147, Annex: United Nations Basic Principles and Guidelines on the Right to a Remedy and Reparation for Victims of Gross Violations of International Human Rights Law and Serious Violations of International Humanitarian Law.

38 Dz.U. z 2005 r. Nr 18, poz. 158.

39 Dz.U. z 2005 r. Nr 18, poz. 160.

40 Dz.U. z 2005 r. Nr 18, poz. 162. 
praktyk mało jeszcze znanych, a tym samym zapoczątkować rzeczywiście nowy etap w rozwijaniu działalności na rzecz ofiar.

Draft of THE UN CONVENTION ON JUSTiCE AND Support For Victims of Crime and Abuse of Power

\section{Summary}

The paper gives an account of the provisions of the draft of the UN Convention on Justice and Support for Victims of Crime and Abuse of Power of 8 February 2010. The aim of the new UN document is to strengthen the position of victims around the world, by extending the scope of the rights granted them under the UN Declaration on Basic Principles of Justice for Victims of Crime and Abuse of Power of 29 November 1985. The description of these rights provides a basis for a discussion of the need of the Convention.

Słowa kluczowe: wiktymologia,prawo ofiar przestępstw, Deklaracja ONZ 1985, restytucja i reparacja, państwowa kompensata

Keywords: victimology, rights of crime victims, UN Declaration 1985, restitution and reparation, state compensation 